Original Research Paper

\title{
Evaluation the Anaerobic Digestion Performance of Organic Waste from a Landfill in Morocco
}

\author{
Fatima Ebich, Rajae Ramdan and Azzouz Essamri \\ Laboratory of Agroresources and Process Engineering, \\ University Ibn Tofail, Faculty of Sciences, Kenitra, Morocco
}

Article history

Received: 11-01-2017

Revised: 20-09-2017

Accepted: 25-09-2017

Corresponding Author:

Fatima Ebich

Laboratory of Agroresources

and Process Engineering,

University Ibn Tofail, Faculty

of Sciences, Kenitra, Morocco

Email: fatimaebich@hotmail.com

\begin{abstract}
Organic household waste has a high organic content (69 g/ kg), value of $\mathrm{pH}$ equal to 6,3 with $94 \%$ of moisture. Anaerobic digestion is one of the technologies for recycling and stabilization of organic waste, the process is carried out in $3 \mathrm{~L}$ reactor at semi continuous and mesophelic conditions. During the anaerobic digestion of $\mathrm{OHW}, \mathrm{pH}$ was around neutrality (between 6,5 and 8), a decrease of alkalinity was observed reaching a value of $900 \mathrm{mg}$ $\mathrm{CaCo}_{3} / \mathrm{L}$ ), total and volatile solid were accumulated at the end of the experiment. Result of biogas production indicates that a higher methane yield was obtained for the load $0,5 \mathrm{~g} \mathrm{VS} / \mathrm{L}$, methanogenic potential for the anaerobic digestion of OHW was $0,15 \mathrm{~L}_{\mathrm{STP}} / \mathrm{g}$ VS.
\end{abstract}

Keywords: Methane, Alkalinity, Digester

\section{Introduction}

In recent decades, rapid urbanization of cities has led to a proliferation of uncontrolled landfills (El Khamlichi, 1997). The production of household waste in urban areas is about 11000 tonnes/day. These waste consists mainly of organic material (50 to $70 \%$ ), paper-cardboard (5 to $10 \%$ ) of plastic (6 to $8 \%$ ) of metal (1 to 4\%) and glass (1-2\%) (Ajir, 2002). The household waste in Morocco and other developing countries is characterized by higher moisture (60$70 \%$ ); calorific value of 900 to $1000 \mathrm{kcal} / \mathrm{kg}$, in contrast to industrialized countries in which household waste is characterized by a $40 \%$ rate of combustible materials with a moisture content substantially lower "<50\%) (Soudi, 2001).

the treatment of household waste, especially, remains very underdeveloped outside the wild landfill that has a harmful effect on the environment (soil pollution, water resources and greenhouse gas emissions). Alternative processing technologies, such as Anaerobic Digestion (AD), offer some potential for the recovery of valuable resources and the reduction of organic compounds from organic wastes by producing biogas (Carvalheiro et al., 2008; Stabnikova et al., 2008). Anaerobic digestion has been considered as a promising process for organic waste removal coupled with renewable energy generation (Scano et al., 2014; Yangin-Gomec and Ozturk, 2013).

\section{Materials and Methods}

\section{Substrate}

Organic household waste was collected from an uncontrolled landfill in Meknes city and mixed using a blender, its composition is shown in Fig. 1 and Table 1 shows the main characteristics of OHW.

\section{Inoculum}

The inoculum was collected from a mesophilic anaerobic reactor of wastewater plant in Marrakech. The inoculum was selected on the basis of their high methanogenic activity (Field et al., 1988) and mixed with digestate obtained from a batch anaerobic digester of household waste, chemical composition of inocula is shown in Table 2.

\section{Anaerobic Digester and Experimental Procedure}

The experiment was conducted in laboratory glass bottles of $3 \mathrm{~L}$ volume, which served as semi continuous mode anaerobic reactor working under mesophilic temperature, it was equipped with two connections to load substrate and ventilate methane gas and magnetically stirred by means of an electromagnetic stirrer connected to a motor. The volume of methane produced during the process was measured using 2-L reservoirs connected to the reactor. To remove the $\mathrm{CO}_{2}$ produced during the process, tightly closed bubblers containing a $\mathrm{NaOH}$ solution $(6$ N) were connected between the two elements. 


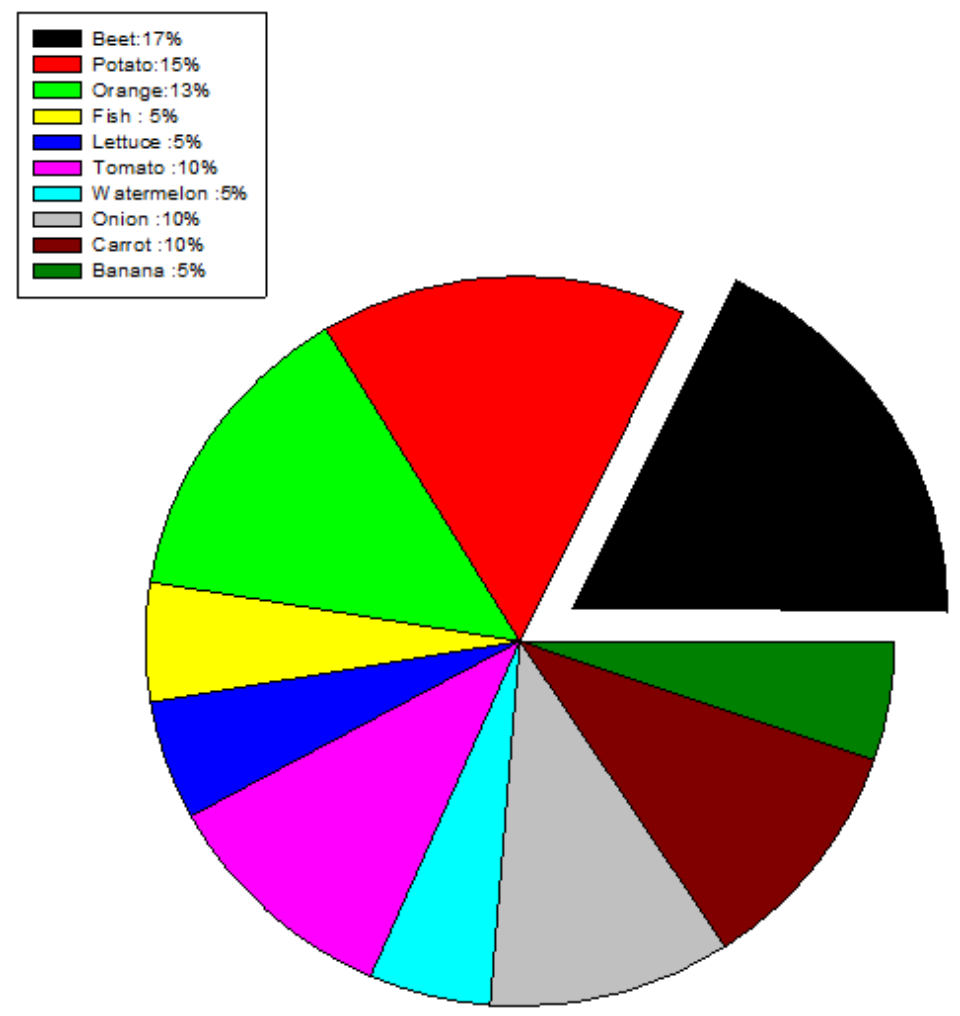

Fig. 1. Composition of OHW

Table 1. Chemical characteristics of OHW

\begin{tabular}{lll}
\hline Parameters & Units & Values \\
\hline $\mathrm{pH}$ & - & 5,3 \\
Moisture & $\%$ & 94 \\
Total solids & $\mathrm{g} / \mathrm{kg}$ & 72 \\
Volatile solids & $\mathrm{g} / \mathrm{kg}$ & 69 \\
Mineral solids & $\mathrm{g} / \mathrm{kg}$ & 3 \\
\hline
\end{tabular}

Table 2. Chemical composition of inocula

\begin{tabular}{lll}
\hline Parameters & Units & Values \\
\hline $\mathrm{pH}$ & - & 7,8 \\
Moisture & $\%$ & 92,5 \\
Total solids & $\mathrm{g} / 1$ & 28 \\
Volatile solids & $\mathrm{g} / 1$ & 18,5 \\
Mineral solids & $\mathrm{g} / 1$ & 9,5 \\
\hline
\end{tabular}

The volume of methane displaced an equal measurable volume of water from the reservoirs. This volume was corrected in order to remove the effect of water steam pressure and the measured methane was then expressed at standard temperature and pressure conditions (STP: 0 _C and $1 \mathrm{~atm}$ ) (Martín et al., 2013).

Reactor was initially loaded with inoculum, after the inoculation stage, it was first fed with $0,5 \mathrm{~g} \mathrm{VS} / \mathrm{L}$, the volume of methane was measured as a function of time and then the organic loads added to the reactors was increased from 1.00 to $3.00 \mathrm{~g} \mathrm{VS} / \mathrm{L}$. $\mathrm{pH}$, alkalinity, total solid and volatile solid were measured before and after each load added to the reactor.

\section{Results and Discussion}

\section{Methane Yield Coefficient and Biodegradability}

Figure 2 shows the methanogenic potential for different loads added to the digester. The maximum of methane yield was observed for the load $0,5 \mathrm{~g} \mathrm{VS} / \mathrm{L}$ and reached of $0,15 \mathrm{~L} / \mathrm{g} \mathrm{VS}$, this value is in line with that found by Gao et al. (2015) who trated residual kitchen waste by anaerobic digestion and a value of $0,479 \mathrm{~L} / \mathrm{g}$ TS was obtained in this study. After that, a rapid decrease of methane yield was observed between the load $1 \mathrm{~g} \mathrm{VS} / \mathrm{L}$ and $3 \mathrm{gVS} / \mathrm{L}$, which indicate a decrease of methane production.

The relation between volatile solid added and volatile solid removed is shown in Fig. 3, a low biodegradability was observed for the anaerobic digestion of organic household waste $(63 \%)$. this might be due to the inhibition or destruction of mathanogenic bactaria by some toxicants contaminating wastes. Figure 4 shows the evolution of the volume of methane accumulated as a function of time for the loads $0,5 \mathrm{~g} \mathrm{VS} / \mathrm{L}$, this volume increase with time due to the degradation of organic matter added which turns into biogas. 


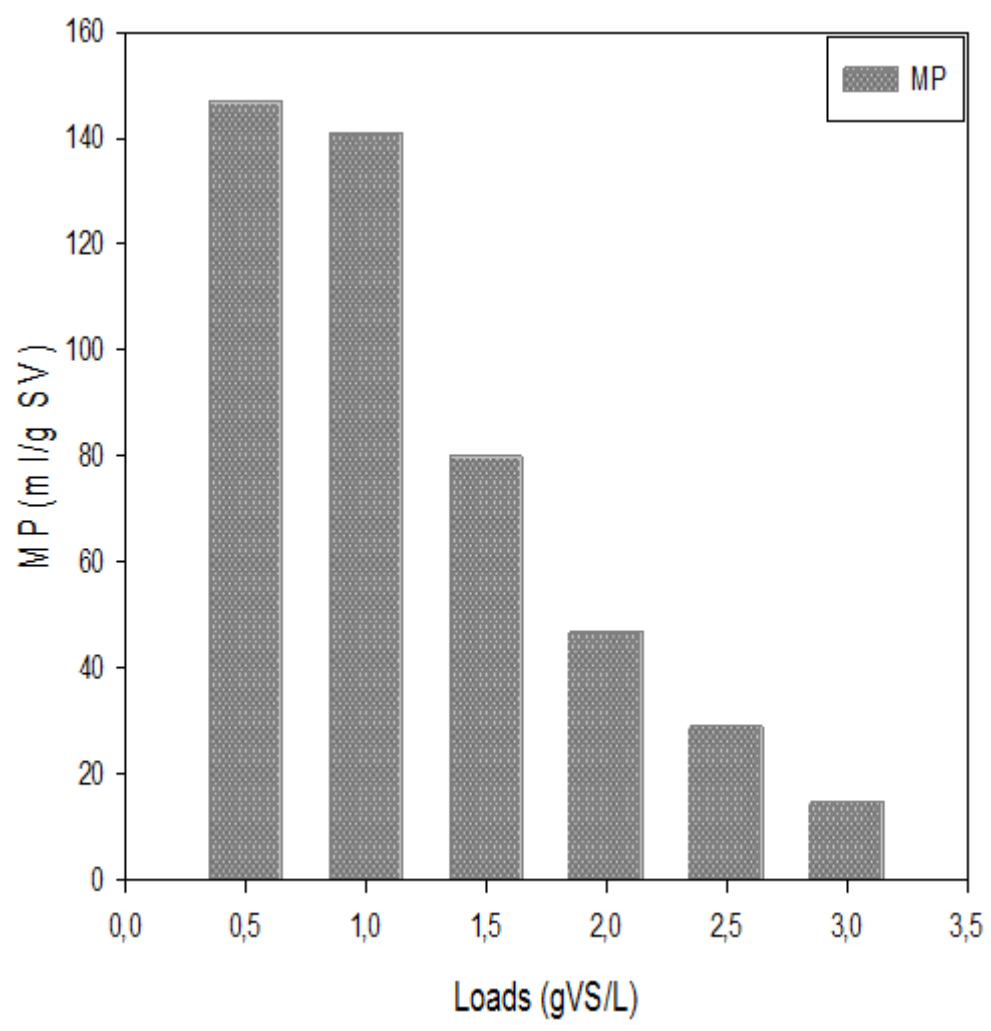

Fig. 2. Methanogenic potential

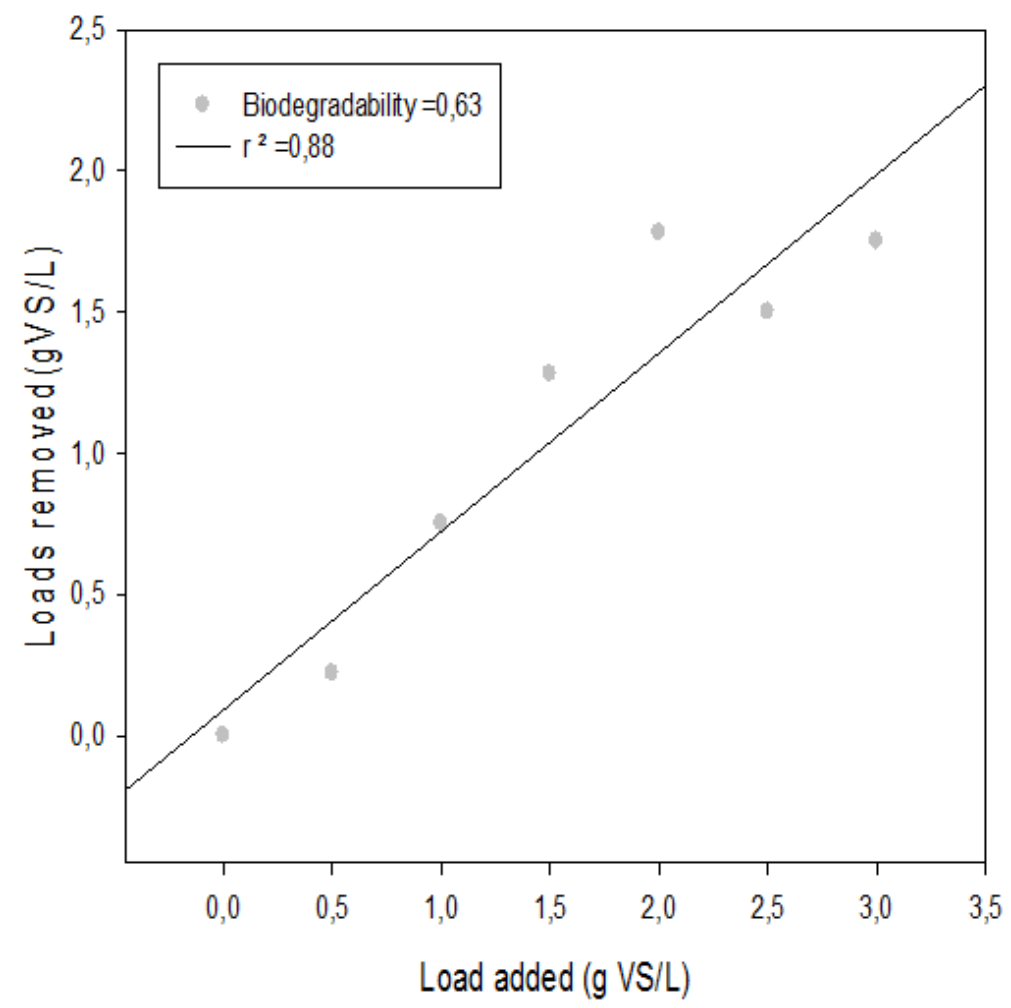

Fig. 3. Biodegradability during mesophilic anaerobic digestion of OHW 


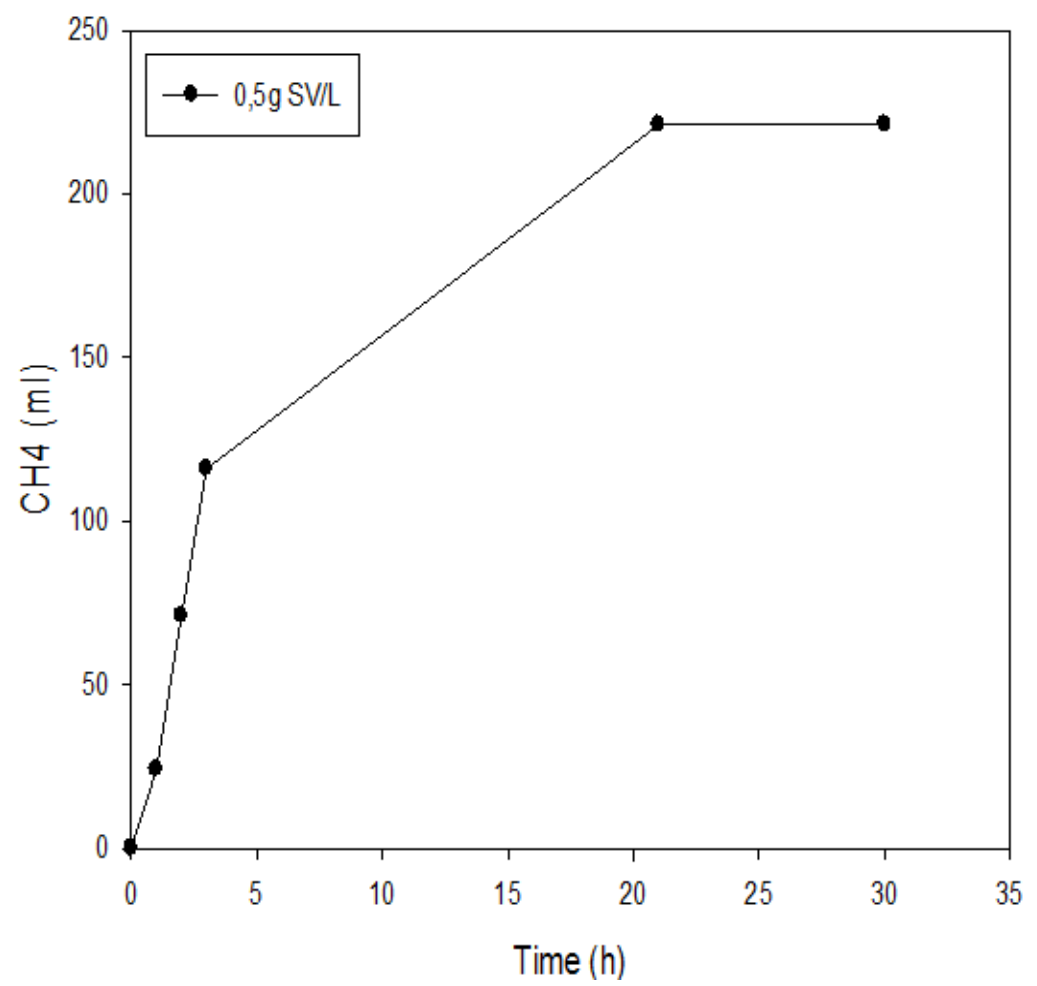

Fig. 4. Variation in the volume of methane accumulated as a function of time for a load of $0.5 \mathrm{~g} \mathrm{VS} / \mathrm{L}$

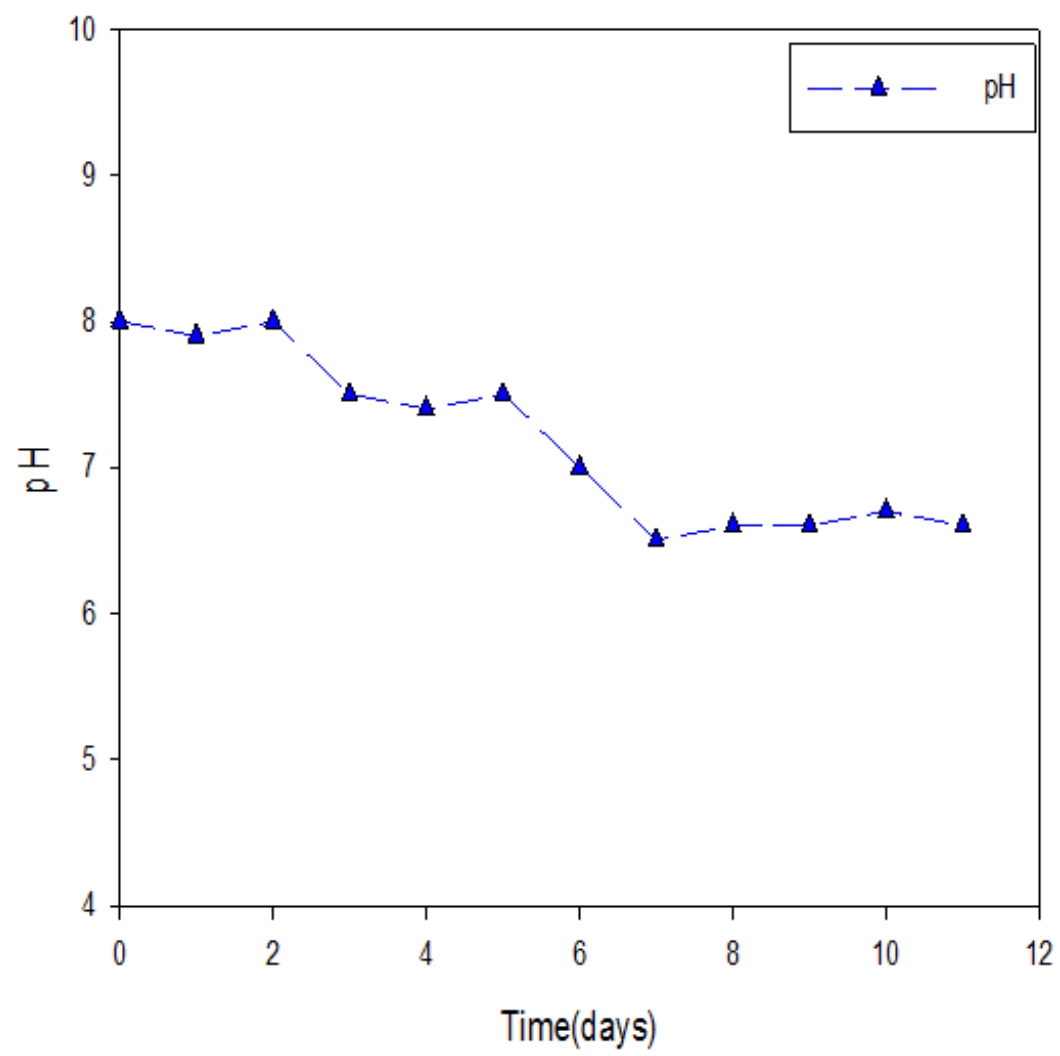

Fig. 5. Evolution of $\mathrm{pH}$ in the digester 
Fatima Ebich et al. / American Journal of Environmental Sciences 2017, 13 (5): 351.357

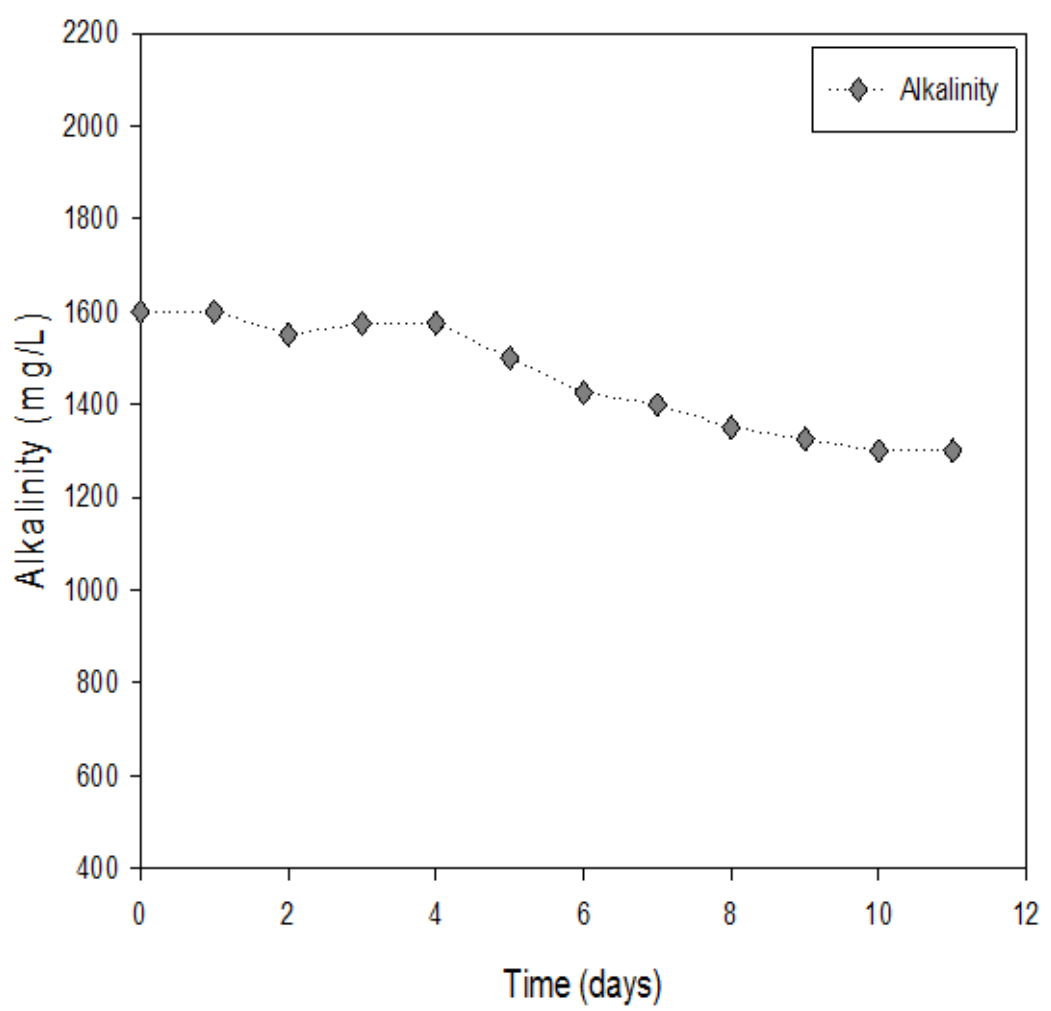

Fig. 6. Alkalinity variation during the digestion of OHW

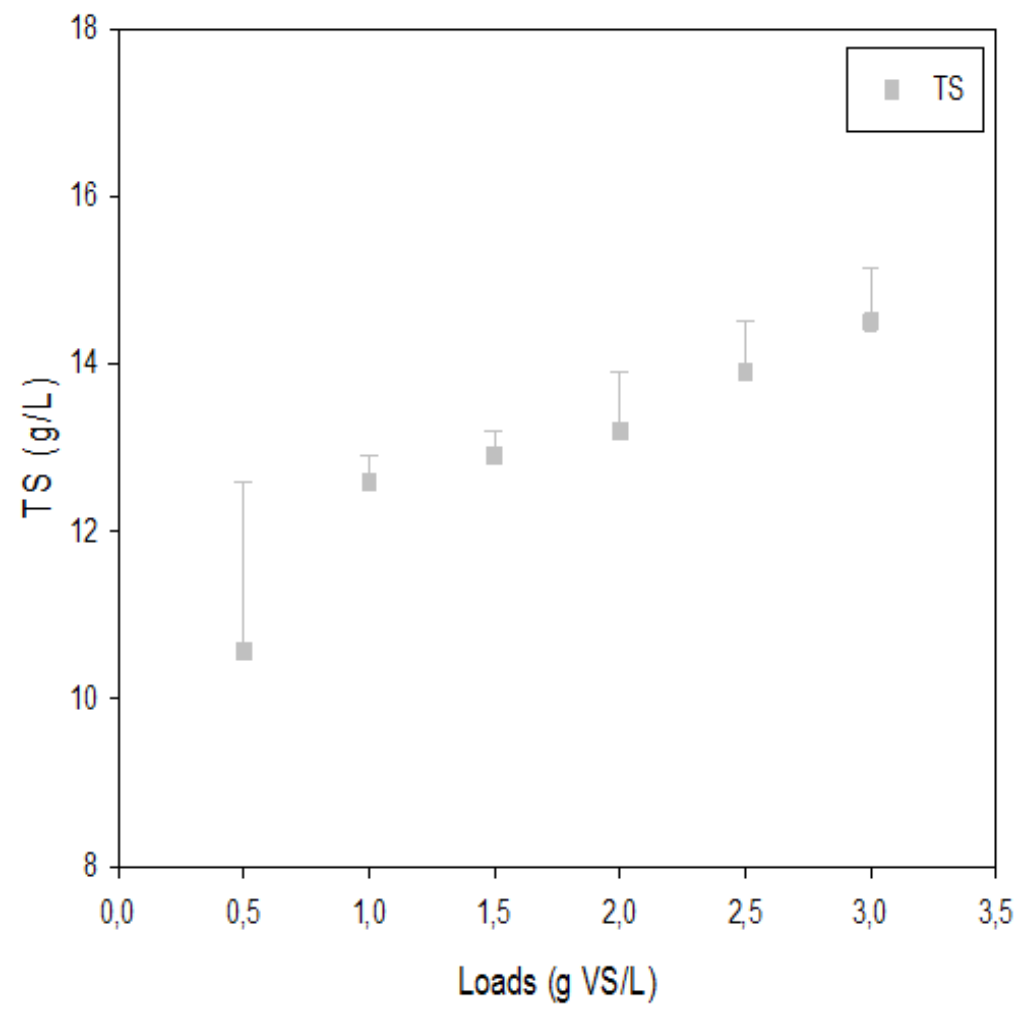

Fig. 7. Total solid variation in the digester 


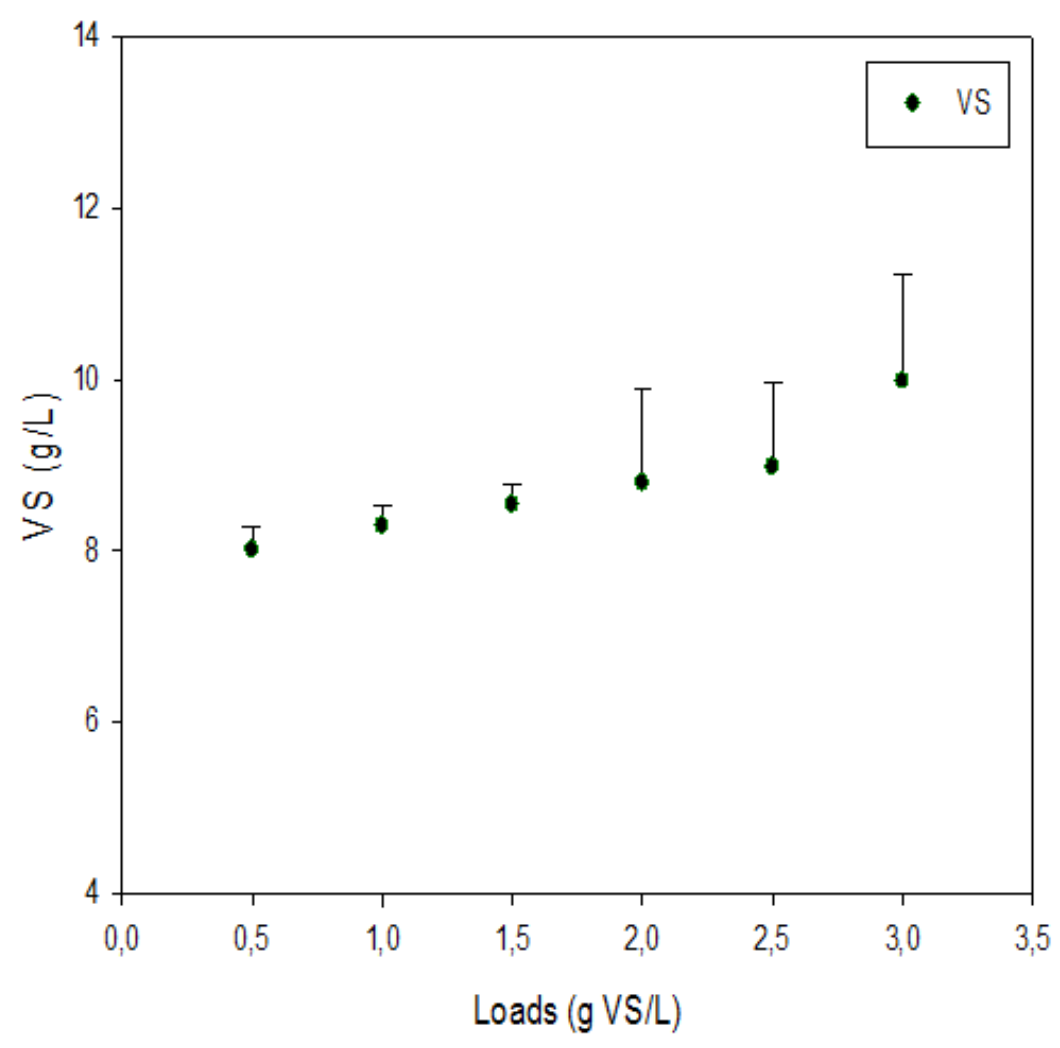

Fig. 8. Volatile solid variation during the experiment

Stability of Digester during Mesophilic Anaerobic Digestion of $\mathrm{OHW}$

\section{Variation of Alkalinity and $\mathrm{pH}$}

The process of anaerobic digestion of OHW is based on $\mathrm{pH}$, alkalinity, total solid and volatile solid to evaluate its stability. The evolution of $\mathrm{pH}$ in the reactor is shown in the Fig. 5, it decreases reaching a value of 6.5 , These values are in line with those previously described by Martín et al. (2010) and Siles et al. (2009) but it was around neutrality because the optimal $\mathrm{pH}$ range for mesophilic anaerobic digestion is close to neutrality, varying for each type of bacteria between 6.5 and 7.5 (Martí, 2006).

Figure 6 shows the variation of alkalinity during the process of mesophilic anaerobic digestion of organic household waste, the alkalinity is one of parameters which evaluate the stability in the effluents of reactor. In this study a rapid decrease in the alkalinity which reached a final value of $1300 \mathrm{mg} \mathrm{CaCO} / / \mathrm{L}$, this decrease indicate a lack of alkali element which are being reaction with acids element that can be found in the substrate.

\section{Evolution of Total and Volatile Solid}

Figure 7 and 8 show the variation of total solid and volatile solid during mesophilic anaerobic digestion of
OHW, it is observed that the concentration of total load and volatile organic content present in the digester is nearly constant before and after the placing of each load, this can be explained by the fact that the substrate brought to the digester is completely degraded under the action of the microorganisms present in the reactor. However, the variation of the total solids and volatile solids is important after load $1.5 \mathrm{~g} \mathrm{VS} / \mathrm{L}$ where there was an increase of these two parameters with the increasing the amount of the substrate brought in the digester (from 0.5 to $3 \mathrm{~g}$ $\mathrm{SV} / \mathrm{L}$ ), this indicates that the substrate provided to the digester is not completely biodegraded thus it was an accumulation of organic matter in the end of experiment.

\section{Conclusion}

The results obtained through this research reveal that the semi continuous anaerobic digestion of OHW was unstable where the methanogenic potential decrease rapidly reached a value of $17 \mathrm{~mL}$ STP $\mathrm{CH}_{4} / \mathrm{g}$ VS for the load $3 \mathrm{~g} \mathrm{VS} / \mathrm{L}$. Through this experiment, $\mathrm{pH}$ was around neutrality and alkalinity decrease which indicate a lack of alkali element. The remaining sludge generated from the anaerobic digestion of $\mathrm{OWH}$ at the end of experiment is used as fertilizer for agricultural grounds because is 
rich in mineral elements (phosphorus, potassium, magnesium, ammonium, Nitrate, Sodium, Calcium...).

\section{Author's Contributions}

All authors equally contributed in this work.

\section{Ethics}

This article is original and contains unpublished material. The corresponding author confirms that all of the other authors have read and approved the manuscript and there are no ethical issues involved.

\section{References}

Ajir, A., 2002. Gestion des déchets solides au Maroc: Problématique et approche de développement. Proceedings of the International Symposium on Environmental Pollution Control and Waste Management, Jan. 7-10, Tunis pp: 740-747.

Carvalheiro, F., L.C. Duarte and F.M. Gírio, 2008. Hemicellulose biorefineries: A review on biomass pretreatments. J. Sci. Ind. Res., 67: 849-864.

El Khamlichi, M.A., 1997. Revue marocaine du Génie Civil.

Field, J., R. Sierra and G. Lettinga, 1988. Ensayos Anaerobios. In: $4^{\circ}$ Seminario de Depuration Anaerobia de Aguas Residuales, Fdz-Polanco, F., P.A. Garcia and S. Hernando (Eds.), Secretariado de Publicaciones, Universidad de Valladolid, Valladolid, Spain, pp: 52-82.

Gao, S., Y. Huang, L. Yang, H. Wang and M. Zhao et al., 2015. Evaluation the anaerobic digestion performance of solid residual kitchen waste by $\mathrm{NaHCO}_{3}$ buffering. Energy Convers. Manage., 93: 166-174.

DOI: $10.1016 /$ j.enconman.2015.01.010
Martí, N., 2006. Phosphorus precipitation in anaerobic digestion process. Dissertation.com. Boca Raton, Florida.

Martín, M.A., J.A. Siles, A.F. Chica and A. Martín, 2010. Biomethanization of orange peel waste. Bioresource Technol., 101: 8993-8999. DOI: $10.1016 /$ j.biortech.2010.06.133

Martín, M.A., R. Fernández, A. Serrano and J.A. Siles, 2013. Semi-continuous anaerobic co-digestion of orange peel waste and residual glycerol derived from biodiesel manufacturing. Waste Manage., 33: 1633-1639. DOI: 10.1016/j.wasman.2013.03.027

Scano, E.A., C. Asquer, A. Pistis, L. Ortu and V. Demontis et al., 2014. Biogas from anaerobic digestion of fruit and vegetable wastes: Experimental results on pilot-scale and preliminary performance evaluation of a full-scale power plant. Energy Convers. Manage., 77: 22-30. DOI: 10.1016/j.enconman.2013.09.004

Siles, J.A., M.A. Martín, A.F. Chica and A. Martín, 2009. Anaerobic digestion of glycerol derived from biodiesel manufacturing. Bioresource Technol., 100: 5609-5615. DOI: 10.1016/j.biortech.2009.06.017

Soudi, B., 2001. Compostage des déchets ménagers et valorisation du compost: Cas des petites et moyennes communes au Maroc. Revue H.T.E. N 121.

Stabnikova, O., X.Y. Liu and J.Y. Wang, 2008. Digestion of frozen/thawed food waste in the hybrid anaerobic solid-liquid system. Waste Manage., 28: 1654-1659. PMID: 17826973

Yangin-Gomec, C. and I. Ozturk, 2013. Effect of maize silage addition on biomethane recovery from mesophilic co-digestion of chicken and cattle manure to suppress ammonia inhibition. Energy Convers. Manage., 71: 92-100. DOI: 10.1016/j.enconman.2013.03.020 